\title{
Engineering Properties and Applications of Air-Foamed Lightweight Soil
}

\author{
Xuze Yuan $\left(\mathbb{D},{ }^{1,2}\right.$ Zheng Lu $\left(\mathbb{D},{ }^{1,3}\right.$ Hailin Yao, ${ }^{1}$ Xianjun Tan $\left(\mathbb{D},{ }^{1}\right.$ Yang Zhao $\mathbb{D},{ }^{1,2}$ \\ Chuxuan Tang $\oplus^{1,2}$ Ming Cheng, ${ }^{4}$ and YiPeng Gao $\oplus^{5}$ \\ ${ }^{1}$ State Key Laboratory of Geomechanics and Geotechnical Engineering, Institute of Rock and Soil Mechanics, \\ Chinese Academy of Sciences, Wuhan 430071, China \\ ${ }^{2}$ University of Chinese Academy of Sciences, Beijing 100049, China \\ ${ }^{3}$ Hubei Key Laboratory of Geo-Environmental Engineering, Wuhan 430071, China \\ ${ }^{4}$ Jilin Provincial Transport Scientific Research Institute, Changchun 130012, China \\ ${ }^{5}$ Beijing Jiaotong University, Beijing 100049, China
}

Correspondence should be addressed to Zheng Lu; zlu@whrsm.ac.cn and Xianjun Tan; xjtan@whrsm.ac.cn

Received 9 October 2021; Revised 23 December 2021; Accepted 5 January 2022; Published 21 January 2022

Academic Editor: Sakar Mohan

Copyright (c) 2022 Xuze Yuan et al. This is an open access article distributed under the Creative Commons Attribution License, which permits unrestricted use, distribution, and reproduction in any medium, provided the original work is properly cited.

With the continuous development of road construction worldwide, the construction sector is trying to find a versatile material for building roads in particular areas. Air-foamed lightweight soil, which is produced using low-cost raw materials and has a lower density varying from 300 to $1800 \mathrm{~kg} / \mathrm{m}^{3}$, adjustable strength, excellent thermal isolation, and a more straightforward construction method, has emerged as a worthy candidate. This paper reviews air-foamed lightweight soil in terms of its composition as well as physical and mechanical properties, such as its compressive strength, flexural strength, and stability. This paper also generalizes the engineering applications of air-foamed lightweight soil and provides ideas for its wide use.

\section{Introduction}

With the continuous development of road construction worldwide, building roads in sand, frozen soil, soft soil, and other areas has become inevitable. However, traditional techniques, including soil reinforcements and pile foundation processing, have some shortcomings such as poor durability, high price, and difficulty in construction [1-4]. Therefore, finding economical, universal, and convenient construction techniques has become an unremitting pursuit of scientists and engineers. As a result, air-foamed lightweight soil applications are increasing at a high rate. Owing to its lightweight and porous properties, air-foamed lightweight soil can effectively reduce subgrade settlement and alleviate the influence of external temperature changes on the subgrade; thus, it is considered an excellent roadbuilding material.

Lightweight air-foamed soil is a light geotechnical material that is fully mixed and stirred by adding a curing agent, water, and a premade air bubble group in a certain proportion to raw soil [5]. The raw soil can be fine sand, fly ash, and silt; thus, the properties of lightweight air-foamed soil can be customized to particular uses and occasions [6-8]. The main characteristics of air-foamed lightweight soil are that it contains foam holes in the mortar, which make it lighter than other soils, and its bulk density is smaller than that of traditional soil. In addition to these characteristics, it has excellent thermal isolation properties and an adjustable strength, is easier to pump than other materials, and has lowcost raw materials used in its production [5, 9-12].

Air-foamed lightweight soil was invented in the 1980s and borrowed autoclaved aerated concrete technology and foamed concrete technology; as a result, it is not much different from foam concrete in terms of hardening $[13,14]$. However, in terms of application fields, the two soils are significantly different: foamed concrete is often used for building energy conservation and external wall insulation, while air-foamed lightweight soil is more widely used in 
subgrade filling and structural load reduction because of its larger bulk density and lower cost [15-18].

As shown in Figure 1, air-foamed lightweight soil has experienced promising development since the turn of the century, which can be attributed to many reasons, including improvement in the performance of raw materials $[19,20]$ and improvement in preparation and curing skills [21] and continuous exploration of new fields in which it can be applied. For instance, Watabe and Noguchi [22] used airfoamed lightweight soil in the construction of the D-runway at Tokyo Haneda airport to reduce runway settlement. Vo and Park [23] indicated the feasibility of air-foamed lightweight soil as a potential sustainable pavement material. Furthermore, Zhang and Yang [24] used air-foamed lightweight soil as an aircraft arresting system to improve the safety of runway overruns.

This paper provides a summary of past studies on airfoamed lightweight soil, its current development status, uses, limitations, and potential future developments. Furthermore, it describes the constituent materials, basic properties, and application fields. Figure 2 briefly outlines this paper.

\section{Preparation and Proportioning of Air- Foamed Lightweight Soil}

Figure 3 presents the basic components of air-foamed lightweight soil: raw soils, cement, water, and foam. All the materials mentioned above will be described in detail in this section.

2.1. Binder. Ordinary Portland cement, calcium sulfoaluminate cement, and high alumina cement are the dominant binders in air-foamed lightweight soils $[14,15]$. Moreover, fly ash, silica fume, and slag have been the most widely used alternative cement materials in recent years [25-27]. Fly ash can effectively reduce the hydration temperature and enhance the long-term strength of air-foamed lightweight soil $[20,28]$. Slag can strengthen the integrity of air-foamed lightweight soil, improve its compressive strength and flexural strength properties, and prevent the cracking of structures [29-31]. Silica fume increases the compactness of structures and improves the cementation properties of materials $[27,32]$.

In recent years, new cementing materials have informed the development of air-foamed lightweight soil [33-35]. For instance, mixing titanium slag extraction, red gypsum, and cement at a ratio of $10: 45: 45$ can increase the compressive strength of air-foamed lightweight soil to $2.14 \mathrm{MPa}$ [36]. Moreover, the use of mineral gypsum instead of cement could give air-foamed lightweight soil with a density of $600 \mathrm{~kg} / \mathrm{m}^{3}$ a compressive strength of $2 \mathrm{MPa}$ [19].

2.2. Foam Agent. Foam is an essential component of airfoamed lightweight soil and is defined as enclosed air voids formed by the addition of foam agents [37]. Common foam agents fall into two categories: chemical and physical foaming agents. Aluminum powder and hydrogen peroxide are the most common chemical foaming agents [38, 39].
Because the chemical reactions of chemical foaming agents are violent, the amounts of reacting material and reaction conditions must be strictly controlled. Therefore, chemical foaming agents are often used to prepare ultra-light-foamed soils with high requirements [40, 41]. Unlike chemical foaming agents, physical foaming agents use high-speed mixing, compressed air, and other mechanical means to introduce air into the foaming solution. As a result, the foaming process is easier to control, and the resulting foam is more stable than that formed with chemical foaming agents [42-44]. Ordinary physical foaming agents include Rosin foaming agents, synthetic foaming agents, protein foaming agents, and compound foaming agents [45, 46], among which protein and compound foaming agents have become the most widely used foaming agents owing to their higher foaming rate and more stable foaming effect [47-50].

2.3. Aggregates. A material with a diameter less than $4.75 \mathrm{~mm}$ is used to make air-foamed lightweight soil (i.e., fine aggregate) to prevent the resulting soil from being damaged by large particles, which would cause a defoaming phenomenon [29]. Untreated soil construction waste or other novel materials can be used as aggregates [51-55]. Table 1 provides a summary of some lightweight aggregate types and their typical characteristics.

2.4. Water. Water does not affect the strength and durability of air-foamed lightweight soil. Drinking water, tap water, river water, lake water, and fish pond water can all be used in the preparation of air-foamed lightweight soil [42]. The water content depends on many factors, including the type of aggregates, binder materials, and desired density [59]. A low water content generates rigid mixtures and causes the foam to break during mixing; a high water content may cause the slurry to become too thin to hold the foam $[25,26]$. For clay, a water content higher than 1.9 times the water limit $\left(w_{L}\right)$ is recommended for the production of air-foamed lightweight clays [60]. However, for other soil types, the water-to-cement ratio should range from 0.4 to 1.25 . If the maximum value is used, superplasticizer is typically not added to the mixture $[61,62]$.

2.5. Mix Proportion of Air-Foamed Lightweight Soil. The mixed proportion of air-foamed lightweight soil influences the relationship between the binder, water, foam, and aggregate materials. The mix ratio is usually obtained by experiment [14], so Table 2 summarizes the mixed proportions obtained through various experiments.

Moreover, Horpibulsuk proposed the void/cement ratio (V/C) [60], which is defined as the ratio of the void volume of clay to the cement volume. Jongpradist et al. [68] proposed the concept of effective porosity ratio under different test conditions for samples with different saturation conditions, curing times, and mixing components. Li et al. [69] proposed a method based on the product of the dry density and empirical coefficient. All these methods lend support to the study of air-foamed lightweight soil mixture ratios based 


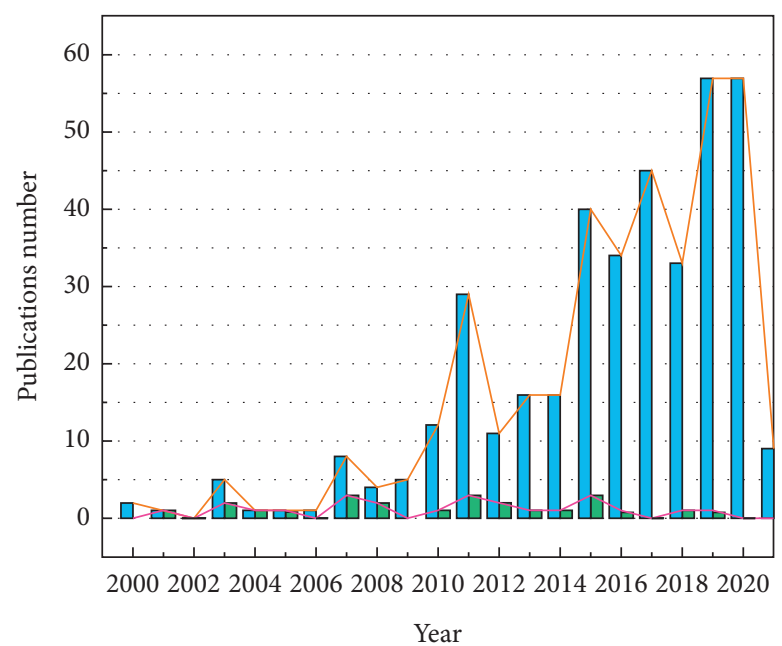

Theme of air-foamed lightweight soil publications related to air-foamed lightweight soil

Figure 1: Numbers of research papers by year (as of April 9, 2021) based on online databases in Web of Science.

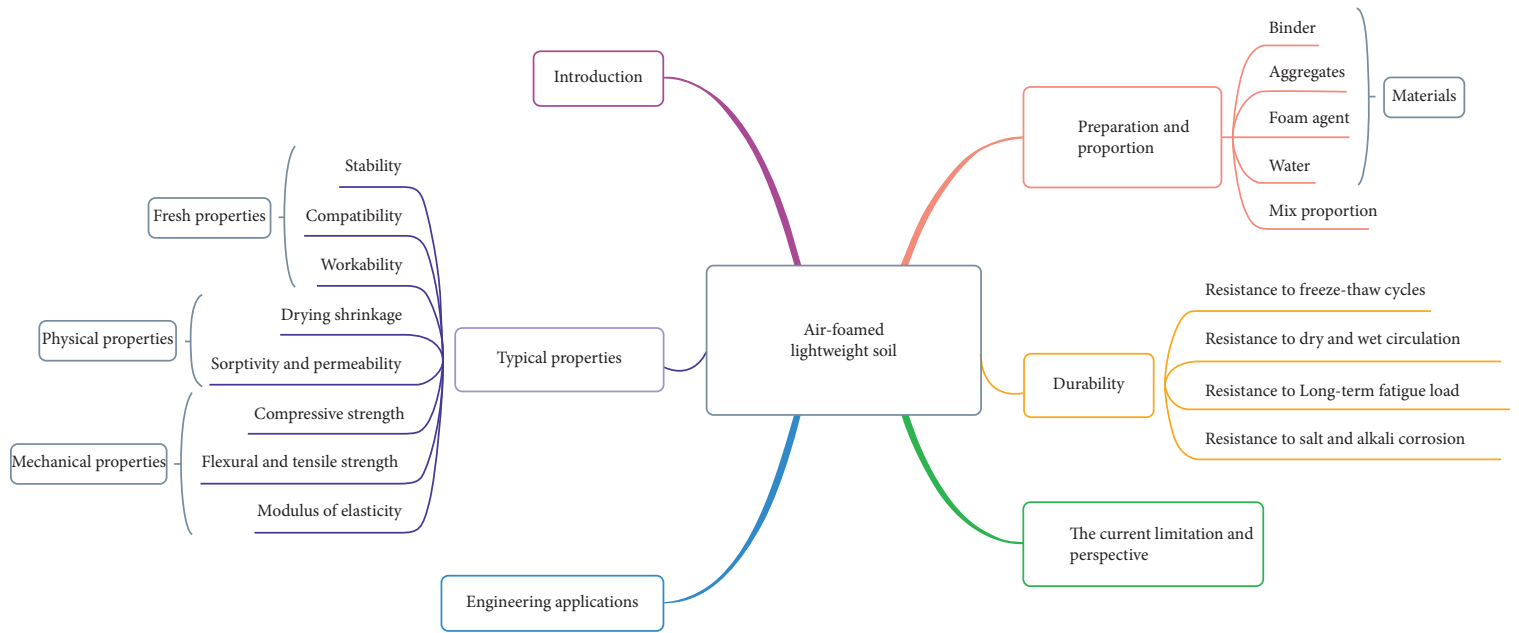

FIGURE 2: Research review outline.

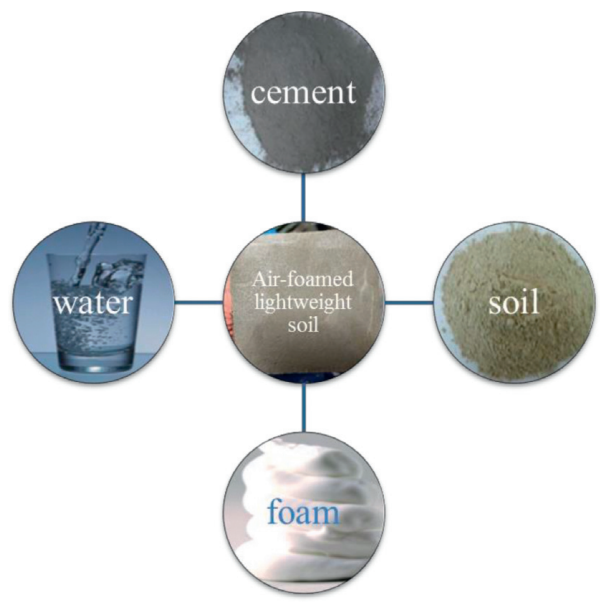

Figure 3: Materials for air-foamed lightweight soil. 
TABLE 1: Summary of the aggregates of air-foamed lightweight soil and their typical characteristics.

\begin{tabular}{lcr}
\hline Author(s) & Aggregate & Typical characteristics \\
\hline $\begin{array}{l}\text { Peng et al. [56] } \\
\text { Jiani et al. [57] }\end{array}$ & $\begin{array}{c}\text { Waste bauxite } \\
\text { tailings }\end{array}$ & $\begin{array}{r}\text { Waste bauxite tailing can maintain the lightweight attributes and high strength of air-foamed } \\
\text { lightweight soil. Moreover, as a material, it has mass production potential. }\end{array}$ \\
$\begin{array}{l}\text { Yang and Chen } \\
\text { [6] }\end{array}$ & $\begin{array}{r}\text { Soil + silica fume husk ash can produce a pozzolanic effect that improves the performance of air-foamed } \\
\text { lightweight soil. }\end{array}$ & $\begin{array}{r}\text { Using soil instead of sand can reduce the dry density of air-foamed lightweight soil. Adding some } \\
\text { silica fume can improve its compressive strength. }\end{array}$ \\
Lim et al. [8] & Quarry waste & $\begin{array}{r}\text { Under a certain lime ratio, the use of a large volume of quarry waste can reduce fluidity and improve } \\
\text { the compressive strength and thermal conductivity of air-foamed lightweight soil. }\end{array}$ \\
Lim et al. [58] & Palm oil fuel ash & $\begin{array}{r}\text { Air-foamed lightweight soil with a certain percentage of palm oil fuel ash replacement filler exhibits } \\
\text { a better strength performance than that containing sand filler. }\end{array}$ \\
\hline
\end{tabular}

TABLE 2: Summary of the mixed proportions obtained by experiment.

\begin{tabular}{|c|c|c|c|c|c|c|}
\hline Authors & Target density & $\begin{array}{l}\text { The type of } \\
\text { raw soil }\end{array}$ & $\begin{array}{l}\text { Cement } \\
\text { content }\end{array}$ & Water content & Foam content & Strength \\
\hline Kim et al. [63] & $\begin{array}{c}400-1100 \mathrm{~kg} / \\
\mathrm{m}^{3}\end{array}$ & Sand & $\begin{array}{l}\mathrm{c} / \mathrm{s}=1: 3,1: \\
2,1: 1,1: 0\end{array}$ & $w / c=0.5-1.2$ & $\begin{array}{l}\text { The foaming agent was } \\
\text { diluted with water in a } \\
\text { ratio of } 1: 19 \text { to achieve } \\
\text { the target density }\end{array}$ & $\begin{array}{c}\text { UC for } \\
28 \mathrm{~d}=65-4940 \mathrm{KPa}\end{array}$ \\
\hline He et al. [64] & $\begin{array}{c}591-1124 \mathrm{~kg} / \\
\mathrm{m}^{3}\end{array}$ & $\begin{array}{l}\text { Cohesive } \\
\text { soil }\end{array}$ & $\begin{array}{c}c / s=10 \%- \\
20 \%\end{array}$ & $w / s=60 \%-80 \%$ & $\begin{array}{c}4 \%-12 \% \text { by weight of } \\
\text { soil }\end{array}$ & $\begin{array}{c}\text { UC for } \\
27 \mathrm{~d}=300-800 \mathrm{KPa}\end{array}$ \\
\hline $\begin{array}{l}\text { Neramitkornburi } \\
\text { et al. [65] }\end{array}$ & $\begin{array}{c}1000-1800 \mathrm{~kg} / \\
\mathrm{m}^{3}\end{array}$ & $\begin{array}{l}\text { Bangkok } \\
\text { clay and fly } \\
\text { ash }\end{array}$ & $\mathrm{c} / \mathrm{s}=5 \%-20 \%$ & $2 w_{L}$ and $3 w_{L}$ & $\begin{array}{l}\text { The air content is } \\
0-100 \%\end{array}$ & $300-2000 \mathrm{KPa}$ \\
\hline $\begin{array}{l}\text { De-Sarno et al. } \\
{[66]}\end{array}$ & $\begin{array}{c}700-1400 \mathrm{~kg} / \\
\mathrm{m}^{3}\end{array}$ & Kaolinite & $\begin{array}{c}c / s=20 \% \\
40 \%\end{array}$ & 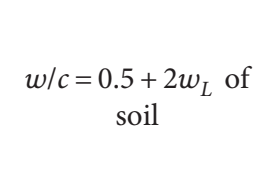 & $\begin{array}{c}\eta_{f}=V_{f} / V=20 \% \text { and } \\
40 \%\end{array}$ & $\begin{array}{l}\text { Direct shear tests on } \\
\text { treated kaolin after } 28 \mathrm{~d} \\
\text { of curing with } \\
\sigma_{\mathrm{v}}{ }^{\prime}=50 \mathrm{kPa} \text { is } \\
0-100 \mathrm{KPa}\end{array}$ \\
\hline Lin et al. [67] & -ー-ー & Silty soil & $\begin{array}{l}58.3 \%, 61.5 \% \text {, } \\
\text { and } 64.3 \% \text { by } \\
\text { weight of soil } \\
\text { and cement }\end{array}$ & $\begin{array}{l}35 \%, 40 \% \text {, and } 50 \% \\
\text { by the weight of soil } \\
\text { and cement }\end{array}$ & $\begin{array}{c}1.5 \%, 2 \% \text {, and } 3 \% \text { by } \\
\text { weight of soil and } \\
\text { cement }\end{array}$ & CBR can reach $9.6 \%$ \\
\hline Vo and Park. [23] & ---- & $\begin{array}{l}\text { Untreated } \\
\text { soil }\end{array}$ & $\begin{array}{l}10 \%-20 \% \text { by } \\
\text { weight of } \\
\text { untreated soil }\end{array}$ & $\begin{array}{l}\text { Add water so that } \\
\text { the density of the } \\
\text { untreated soil is } \\
1650-1750 \mathrm{~kg} / \mathrm{m}^{3}\end{array}$ & $\begin{array}{c}20 \%-40 \% \text { by volume of } \\
\text { untreated soil }\end{array}$ & $\begin{array}{c}0.25-1.6 \mathrm{MPa} \text { at } 28 \mathrm{~d} \\
\text { curing }\end{array}$ \\
\hline
\end{tabular}

Note: $C$ : mass of cement; $S$ : mass of soil; $W$ : mass of water; $w_{L}:$ water limit of soil; UC: unconfined compressive strength; $\eta_{f}:$ porosity; $V_{f}$ : volume of foam; V: theoretical total volume; CBR: California bearing ratio.

on theory and formula. The following formula is the calculation method provided by the Chinese standard CJJ/ T177-2012 [42]:

$$
\begin{aligned}
& \frac{m_{c}}{\rho_{c}}+\frac{m_{w}}{\rho_{w}}+\frac{m_{f}}{\rho_{f}}+\frac{m_{s}}{\rho_{s}}+\frac{m_{m}}{\rho_{m}}=1, \\
& m_{c}+m_{w}+m_{f}+m_{s}+m_{m}=100 \gamma .
\end{aligned}
$$

$m_{c}, m_{w}, m_{f}, m_{s}$, and $m_{m}$ : mass of cement, water, foaming group, aggregates, and admixture per cubic meter $(\mathrm{kg})$, respectively $\rho_{c}, \rho_{w}, \rho_{f}, \rho_{s}$, and $\rho_{m}$ : density of cement, water, foaming group, aggregates, and admixture $\left(\mathrm{kg} / \mathrm{m}^{3}\right)$, respectively $\gamma$ : unit weight of air-foamed lightweight soil

\section{Typical Properties of Air-Foamed Lightweight Soil}

The typical properties of air-foamed lightweight soil are its fresh, physical, mechanical, and durable properties. These properties are influenced by the manufacturing process and performance quality of the air-foamed lightweight soil. In 
this section, these properties are introduced and discussed to guide the application of lightweight air-foamed soil.

\subsection{Fresh Properties}

3.1.1. Stability. The stability of air-foamed lightweight soil ensures the unity of its new density and design density, no bleeding, no segregation, and no apparent defoaming phenomenon after preparation [15]. Wet density is an important index that reflects stability [70]. A lower wet density will increase bubble buoyancy, and as a result, bubbles will replace the surrounding solids, causing the airfoamed lightweight soil to collapse [71]. A higher wet density will cause bubbles to break during mixing. Therefore, it is generally considered that $500-1100 \mathrm{~kg} / \mathrm{m}^{3}$ is the optimal wet density of air-foamed lightweight soil [72]. Moreover, the water content of the base mixture ratio also affects the stability of air-foamed lightweight soil. A low water-to-solid ratio can reduce the porosity of the soil, resulting in the formation of a more stable internal structure [73]. Foam size is another crucial factor that affects the stability of airfoamed lightweight soil [74]. The larger the bubble size, the thinner the bubble wall. This causes the gas to diffuse, resulting in instability [71].

3.1.2. Workability. Foam content, aggregate type, and aggregate content are the main factors affecting the workability of the air-foamed lightweight soil. The presence of bubbles improves the workability of air-foamed lightweight soil in engineering applications. However, an excessive foam volume reduces its workability $[26,28]$. The influence of aggregate type and content on air-foamed lightweight soil is most often reflected in the use of clay and sandy soil. At the same ratio, sand is better than clay for workability [63].

Here, we summarize two methods for evaluating the workability of an air-foamed lightweight soil. The method proposed by Brewer measures the spread in two directions. In this method, a sample is placed in a $150 \mathrm{~mm}$ long and $75 \mathrm{~mm}$ diameter open-ended cylinder and raised vertically. The two spread diameters should be calculated as approximately $5 \mathrm{~mm}$ [75]. The other is the one recommended in the standards for China and Korea $[42,63]$. The test method relies on a cylindrical mold with a diameter of $80 \mathrm{~mm}$ and a height of $80 \mathrm{~mm}$. When lifting the mold filled with slurry, a spreading diameter of $180 \pm 20 \mathrm{~mm}$ (China) or $200 \pm 20 \mathrm{~mm}$ (Korea) is suggested.

\subsection{Physical Properties}

3.2.1. Drying Shrinkage. Drying shrinkage is the volume shrinkage phenomenon caused by the evaporation of water and hydration of a mixture after mixing and curing. It has been reported that the shrinkage of air-foamed lightweight soil is between $0.1 \%$ and $0.35 \%$ of the total volume, which is 4-10 times higher than that of ordinary concrete $[14,76]$. Therefore, researchers have used various methods to reduce the drying shrinkage. One involves using other binders, such as lime, silica fume, and fly ash, instead of cement, thereby reducing the hydration heat to overcome drying shrinkage $[77,78]$. Another method is increasing the amount of sand and other aggregates to reduce drying shrinkage [75]. Moreover, fibers can also retain water and delay evaporation, therefore effectively controlling the drying shrinkage $[25,78]$. This is mainly because the addition of fibers inhibits the continuous expansion of microcracks caused by water loss during the hardening process of the cement base material and effectively prevents the generation of new cracks. As a result, the dry-shrinkage resistance of the composite material is significantly improved.

3.2.2. Sorptivity and Permeability. Sorptivity and permeability are characteristics of air-foamed lightweight soil that are related to water absorption and are most closely affected by the number of pores and pore morphology [79]. Water absorption increases with more pores and interconnected pores [15]. In addition, the mineral admixture, water-binder ratio, and type of binder also affect the water absorption of air-foamed lightweight soil $[14,74,80]$. Nambiar and Ramamurthy [79] indicated that, for a given foam content, cement-sand-fly ash mixes showed relatively higher sorptivity than cement-sand mixes and pure cement because they require higher water-solid conditions to achieve a stable and workable mix. Therefore, the water absorption reduces in the following order: cement-sandfly ash $>$ cementsand $>$ cement.

\subsection{Mechanical Properties}

3.3.1. Compressive Strength. Compressive strength is the most basic mechanical property of air-foamed lightweight soil as a subgrade material [5]. The density, water-cement ratio, curing method, type of soil, and state of the foams all affect the compressive strength [81]. Therefore, it is crucial to study these factors to improve the properties of air-foamed lightweight soil.

Density is the most direct factor affecting the compressive strength of air-foamed lightweight soil [15, 81, 82]. If the strength of the cementitious material between the bubbles decreases, the compressive strength of the bubbly lightweight soil also decreases $[25,26]$. Research has shown that when the ratio of cement to sand is $1: 2$ and the ratio of water to cement is 0.9 , the strength of lightweight foam soil with a density of $1100 \mathrm{~kg} / \mathrm{m}^{3}$ is twice that of the lightweight foam soil with a density of $600 \mathrm{~kg} / \mathrm{m}^{3}$ [63].

The type of soil used in the production of air-foamed lightweight soil is another factor that affects the compressive strength of air-foamed lightweight soil. Generally, sand has a higher strength than clay [63], and fine sand can have better strength performance than coarse sand; moreover, kaolin has a better strength performance than bentonite $[25,26,60]$. Furthermore, pozzolanic materials as aggregates can greatly improve the strength of air-foamed lightweight soil owing to the pozzolanic reaction [54].

As for other influencing factors, the importance of the water-cement ratio is self-evident. Researchers have indicated that the strength of air-foamed lightweight soil 
decreases with an increase in the water-cement ratio [83]. When the water-cement ratio is higher than 0.5 , the cement particles can achieve complete hydration. However, it has also been reported that the optimum water-cement ratio is 0.17-0.19 for high-strength air-foamed lightweight soil [14]. Therefore, using a high-efficiency water reducer is the most effective method for improving the strength of air-foamed lightweight soil [84].

The pore structure is a key factor that affects the compressive strength of air-foamed lightweight soil. An airfoamed lightweight soil with a homogeneous distribution of spherical bubbles has a higher compressive strength than that with bubbles that have irregular boundaries or rough openings $[61,85]$, which Otani et al. verified using an industrial X-ray scanner [86]. In addition, Lim et al. [87] indicated that fine sand can cause more uniform air voids than coarse sand.

The curing method is also a critical factor that influences the compressive strength of air-foamed lightweight soil. According to CJJ/T177-2012 [42], a specimen should be sealed with plastic film for 28 days at $20 \pm 2^{\circ} \mathrm{C}$, but Fujiwara et al. reported that in order to obtain the desired compressive strength, the samples should be cured in normal moist air for one day and then in steam where the temperature should be increased at $20^{\circ} \mathrm{C} / \mathrm{h}$ and maintained at $65^{\circ} \mathrm{C}$ for four hours and then cooled in air [88]. Zhou indicated that the temperature difference between preparation and curing is the main factor affecting the strength of air-foamed lightweight soil and also reported that the optimum temperature difference is $5-7^{\circ} \mathrm{C}[21]$.

In addition to changing the above influencing factors to improve the compressive strength of air-foamed lightweight soil, some researchers have proposed using different fibers to reinforce the air-foamed lightweight soil. The addition of fiber can effectively reduce the elongation of microcracks and disperse certain external loads when failure occurs, improving the compressive properties of air-foamed lightweight soil [15]. Polypropylene, glass, coconut, polyvinyl alcohol, and kenaf fibers are the most commonly used fibers [89-91]. Raj et al. [92] indicated that using 0.3\% polyvinyl alcohol fiber can increase the compressive strength of $1600 \mathrm{~kg} / \mathrm{m}^{3}$ air-foamed lightweight soil by $76 \%$. Zamzani et al. [93] proved that adding $0.36 \%$ coconut fiber could increase the compressive strength of $1050 \mathrm{~kg} / \mathrm{m}^{3}$ air-foamed lightweight soil by $46 \%$. Steel fibers have also been used to reinforce lightweight air-foamed soil [94]. However, steel fibers are usually not recommended because of their high density [95]. Therefore, some researchers are exploring the use of new types of fibers. For instance, Mhedi enhanced the performance of air-foamed lightweight soil with waste plastic fibers, and Kim used a waste net as a reinforced fiber $[96,97]$. These methods reduce waste and improve the strength of air-foamed lightweight soil, which addresses multiple challenges at once and is a vital reference idea for subsequent development.

Experiments are the most intuitive way to study the compressive strength of air-foamed lightweight soil. CJJ/ T177-2012 [42] stated that the compressive performance of air-foamed lightweight soil can be evaluated by the unconfined compressive strength obtained from a $100 \times 100 \times 100 \mathrm{~mm}^{3}$ cubic specimen at a loading rate of $2 \mathrm{kN} / \mathrm{s}$. As for the stress-strain characteristics under static triaxial stress, Tan et al. [98] found that the compressive strength of air-foamed lightweight soil increases with an increase in density and confining pressure, and the peak strain is only related to the confining pressure. In other words, the peak strain increases with confining pressure. There was no direct correlation between the peak strain and density. However, the static strength of air-foamed lightweight soil is incomplete for civil engineering applications. The dynamic force is also critical. There are studies showing that the dynamic strength of air-foamed lightweight soil under dry conditions is generally $0.26-0.32$ times the unconfined compressive strength and 0.21-0.38 times under saturated conditions [99]. When air-foamed lightweight soil is applied in railway subgrade, a dynamic three-axis experiment revealed that the strength can reach $0.8 \mathrm{MPa}$ when the designed density is $800 \mathrm{Kg} / \mathrm{m}^{3}$ [100].

Based on strength experiments, researchers have proposed several strength prediction models. In terms of basic theory, Horpibuisuk et al. [60] proposed a strength equation with $\mathrm{V} / \mathrm{C}$ as the variable at a specific curing time, predicting the $28 \mathrm{~d}$ unconfined compressive strength by the $\mathrm{V} / \mathrm{C}$ value at different proportions. Yoon and Kyong [101] adopted the method of integrating cement, foam, and initial moisture content into a normalized coefficient and obtained a formula for estimating the unconfined compressive strength of airfoamed lightweight soil. Furthermore, with the development of computer technology, the use of artificial intelligence to predict the strength of air-foamed lightweight soil has been explored [102, 103], which significantly reduces the number of experiments that need to be conducted and improves the design efficiency.

3.3.2. Flexural and Tensile Strengths. Tensile strength and flexural strength are essentially the ability of a material to resist tensile damage. The flexural strength of air-foamed lightweight soil is lower than that of ordinary concrete and lightweight aggregate concrete [104]; however, the ratio of the flexural strength to the compressive strength $(0.2-0.4)$ is higher than that of ordinary concrete $(0.08-0.1)$ [105].

The addition of fibers is the most effective way of improving the flexural strength of air-foamed lightweight soil [106]. The addition of $0.15 \%$ sisal fiber can increase the flexural strength of air-foamed lightweight soil by $29 \%$ [107] because the crack localization is limited and ductility is improved after the addition of fiber-reinforced materials [50]. In terms of fibers used, polypropylene fiber has been applied more extensively [108-110]. Polypropylene fiber has a better improvement effect than other fibers under the same conditions, and its price is very low $[46,111]$. It has also been reported that adding mineral admixtures can increase the shear capacity between fine particles of sand and foam agents to improve the flexural strength [76]. As for the foaming agent mentioned above, Lim et al. [87] found that a natural foaming agent has a higher flexural strength than a 
synthetic foaming agent and can be easily obtained. Therefore, an appropriate material should be selected to improve the flexural strength of air-foamed lightweight soil.

3.3.3. Modulus of Elasticity. The modulus of elasticity is directly related to the density of a material. When the dry density is $500-1600 \mathrm{~kg} / \mathrm{m}^{3}$, the modulus of elasticity is $1.0-1.2 \mathrm{KN} / \mathrm{m}^{2}$ [112]. The use of fiber and improvement of the fineness of the raw materials are common ways of reinforcing the integrity of air-foamed lightweight soil [14]. It is generally believed that the higher the fine aggregate content, the higher the elastic modulus [15]. Furthermore, the elastic modulus of air-foamed lightweight soil is typically obtained using standard experimental tests. Table 3 provides different empirical formulas used to predict the modulus of elasticity when there is insufficient experimental data.

The resilient modulus is different from the elasticity modulus, which is a parameter applied in road engineering. Vo and Park [23] tested the dynamic resilient modulus of air-foamed lightweight soil as a road base material and determined the relationship between the resilient modulus and unconfined compressive strength $\left(M_{r}=307 q_{u}-49\right)$. Chen et al. [115] obtained the dynamic elastic modulus of air-foamed lightweight soil through a dynamic triaxial test and pointed out that the dynamic elastic modulus increased with an increase in density and frequency.

3.4. Durability Properties. The engineering application of air-foamed lightweight soil is critical first-hand data to study durability. Watebe et al. [116] conducted a ten-year followup study of air-foamed lightweight soil and concluded that indexes such as the bulk density, water content, $\mathrm{pH}$ value, calcium content, shear strength, and compressive yield stress all meet the required performance standards. Huang et al. [117] found that the irregular vibration passing through the top of the subgrade was caused by buoyancy when they observed the durability of an offshore air-foamed lightweight soil subgrade. Liu et al. $[118,119]$ established a durability evaluation method for air-foamed lightweight soil by combining the analytic hierarchy process and fuzzy comprehensive evaluation method with first-hand durability data. However, as direct information on durability is limited, it is essential to study the durability performance of airfoamed lightweight soil, such as its resistance to freeze-thaw cycles, resistance to $\mathrm{w}$-d cycles, resistance to long-term fatigue loads, and resistance to salt and alkali corrosion.

3.4.1. Resistance to Freeze-Thaw Cycles. Air-foamed lightweight soil has a lightweight and porous structure. Freeze-thaw cycle damage of air-foamed lightweight soil is inevitable when the soil is applied in engineering. It has been reported that the freeze-thaw cycle changes the volume of air-foamed lightweight soil by less than $1.5 \%$, which has little effect on the properties of the soil [120]. The main factor causing freeze-thaw damage is the water content: the greater the water content is, the more prone air-foamed lightweight soil is to freeze-thaw cycle damage. However, when the number of freeze-thaw cycles is high, the water content and density of air-foamed lightweight soil will become stable [121]. Therefore, adding a polycarboxylic acid superplasticizer to reduce the water-cement ratio is an effective method for improving the ability of air-foamed lightweight soil to resist freeze-thaw cycles.

\subsubsection{Resistance to Wetting and Drying Cycles.} Lightweight air-foamed soil as a stabilized engineering fill and pavement material often experiences wetting and drying cycles ( $w-d$ cycles) due to weather changes, which damages stabilized pavement structures containing it [122]. It has been reported that the strength of air-foamed lightweight soil decreases with an increase in the $\mathrm{w}$ - $\mathrm{d}$ cycles. However, $\mathrm{Xu}$ et al. [123] found that its durability coefficient only reduced by less than 0.1 through unconfined compressive strength experiments on four kinds of air-foamed lightweight soil after ten $\mathrm{w}-\mathrm{d}$ cycles. Based on the experiment above, Neramitkornburi et al. [124] proposed an equation that takes the initial soaking strength as the index and the number of $\mathrm{w}$-d cycles as the variable to predict the strength of air-foamed lightweight soil.

3.4.3. Resistance to Long-Term Fatigue Load. The long-term fatigue load is a significant index for the application of airfoamed lightweight soil on the road. Research has revealed that the dynamic strength is less than the static strength, and with an increase in density, the weakening effect of a cyclic load becomes gradually significant [125]. Therefore, some researchers have attempted to apply air-foamed lightweight soil in the heavy-haul railway subgrade and have achieved great success under long-term loads [126]. As for the service life of air-foamed lightweight soil, Liu et al. [127] predicted that the average service life of air-foamed lightweight soil is 73 years through an accelerating stress method. It has also been reported that the residual strength of air-foamed lightweight soil will decrease by $52.2 \%$ after 1.2 million load cycles [128]. Therefore, the resistance of air-foamed lightweight soil to long-term fatigue load is acceptable.

3.4.4. Resistance to Salt and Alkali Corrosion. Sulfate and chloride erosion will cause damage to air-foamed lightweight soil in an aggressive environment through a complex mechanism that depends on many factors, such as cement type, water-cement ratio, permeability, concentration, and exposure time [129-131]. In general, the uniform stomatal distribution and closed pore state are the keys to chloride resistance because the air voids act as a buffer that prevents rapid penetration of ions [132]. The effect of sulfates on airfoamed lightweight soil was less than that of chloride. Some researchers put the air-foamed lightweight soil specimens into sodium sulfate and magnesium sulfate for one year and observed a mass loss of $1 \%$ [133]. Therefore, research on the salt and alkali resistance of air-foamed lightweight soil should focus on preventing and controlling the entry of chloride salts. 
TABLE 3: Empirical formulas for predicting the modulus of elasticity $\left(E_{c}\right)$.

\begin{tabular}{lcc}
\hline Authors & Equations & Notes \\
\hline CJJ/T177-2012 [42] & $E_{c}=250 q_{u}$ & $q_{u}$ is the unconfined compressive strength \\
& $E_{c}=0.42 f_{c}^{1.18}$ & $f_{c}$ is the unconfined compressive strength \\
The aggregate is fine sand & $f_{c}$ is the unconfined compressive strength \\
The aggregate is fly ash & \\
$E_{c}=0.99 f_{c}^{0.67}$ & $\rho$ is the wet density of air-foamed lightweight soil \\
$k$ is the content of silty soil
\end{tabular}

3.4.5. Microstructure of Air-Foamed Lightweight Soil. Advances in science and technology have provided a better understanding of the microstructure of materials. In recent years, scanning electron microscope (SEM) has been widely used in research on air-foamed lightweight soil [56, 85]. Through SEM, the internal structure of air-foamed lightweight soil can be clearly observed using different cementitious materials $[76,134,135]$. Figure 4 shows a SEM image of the consolidation of air-foamed lightweight soil with titanium slag and red gypsum as cementitious materials, clearly demonstrating the strengthening mechanisms of the cementitious materials [36]. Moreover, the microstructure of air-foamed lightweight soil is the primary factor affecting its strength. For instance, silica fume improves the strength of air-foamed lightweight soil by changing the pore diameter of the soil [74]; temperature will change the frame structure of air-foamed lightweight soil and influence its compressive strength [136]; and the water-solid ratio affects the compactness of the InterPore material, improving the strength of air-foamed lightweight soil [73]. Thus, it can be seen that advanced technology is very important for understanding and further developing air-foamed lightweight soil.

\section{Applications of Air-Foamed Lightweight Soil}

Air-foamed lightweight soil has been applied in many aspects of road engineering owing to its distinctive properties $[5,14]$. Generally, the application scenarios of air-foamed lightweight soil vary with its density: low-density air-foamed lightweight soil is used for thermal insulation and cavity filling, while high density air-foamed lightweight soil is used in structural applications [18]. This section focuses on the applications of air-foamed lightweight soil in soft soil foundation reinforcement, general road engineering applications, subgrade thermal insulation, and shock-absorbing barriers for airports and regular traffic.

4.1. Soft Soil Foundation Reinforcement. Soft soil foundation reinforcement is the most widespread application of lightweight air-foamed soil. This is primarily because (1) there is a considerable amount of soft clay in the coastal areas of rivers and lakes, which is time-consuming and costly to treat using traditional methods [124]. and (2) air-foamed lightweight soil can produce higher strength when dealing with soils with high specific surface areas, such as clay [7]. Therefore, Japan and South Korea have widely used air-foamed lightweight soil in port and coastal roads, and some of the foundations of famous buildings in these countries, such as the Tokyo International Airport, Kobe Port, and Busan New Mega Port, were constructed with air-foamed lightweight soil $[54,116]$.

In addition, approximately $500000 \mathrm{~m}^{3}$ of air-foamed lightweight soil has been used in various construction projects in Japan, and this consumption is still growing [116]. However, in China and Thailand, air-foamed lightweight soil is commonly applied in soft soil subgrade replacement, which reduces the overlying soil pressure and improves the stability of structures $[65,74,137]$. For example, Huang used air-foamed lightweight soil as a subgrade bed to solve the settlement problem of a soft soil foundation and found that the cumulative settlement at the top surface of the subgrade was $0.68 \mathrm{~mm}$ after 2 million loading cycles, satisfying the operational needs of a high-speed rail [138].

4.2. Road Applications. Air-foamed lightweight soil has been used in many fields of road engineering, such as road widening, bridge jump disposal, steep road fill, load reduction of subgrade in landslide sections, prevention of settlement of soft soil foundations, and permafrost roadbed heat insulation [138-140]. According to the data for the Chongqing urban roadbed widening project, the differential settlement of the air-foamed lightweight soil subgrade is only $25.93 \%$ of the traditional subgrade [16]. Furthermore, in an analysis of an abutment building with air-foamed lightweight soil in Hangzhou Bay Bridge, it was found that when the filling height was $2 \mathrm{~m}$, the settlement was reduced by $65 \%$, and when the filling height was $5 \mathrm{~m}$, the settlement was reduced by $44 \%$ [141], which means that air-foamed lightweight soil can effectively reduce the overburden to solve the problem of jumping off the bridge. Furthermore, the standard for air-foamed lightweight soils in road engineering is in development. It is believed that, with the introduction of standards, the application of air-foamed lightweight soil in the road construction field will be further improved [140].

4.3. Thermal Insulation. Air-foamed lightweight soil has excellent thermal insulation properties because of its porosity [14]; it is an excellent material to use in permafrost roadbed heat insulation. It has been reported that the thermal conductivity of air-foamed lightweight soil can reach $0.66 \mathrm{~W} / \mathrm{mK}$ at a density of $1600 \mathrm{Kg} / \mathrm{m}^{3}$, which is $60 \%$ lower than that of ordinary concrete at a density of $2200 \mathrm{Kg} /$ $\mathrm{m}^{3}$ [142], and the thermal conductivity decreases by $0.04 \mathrm{~W} /$ $\mathrm{mK}$ for every $100 \mathrm{Kg} / \mathrm{m}^{3}$ decrease in density [143]. 


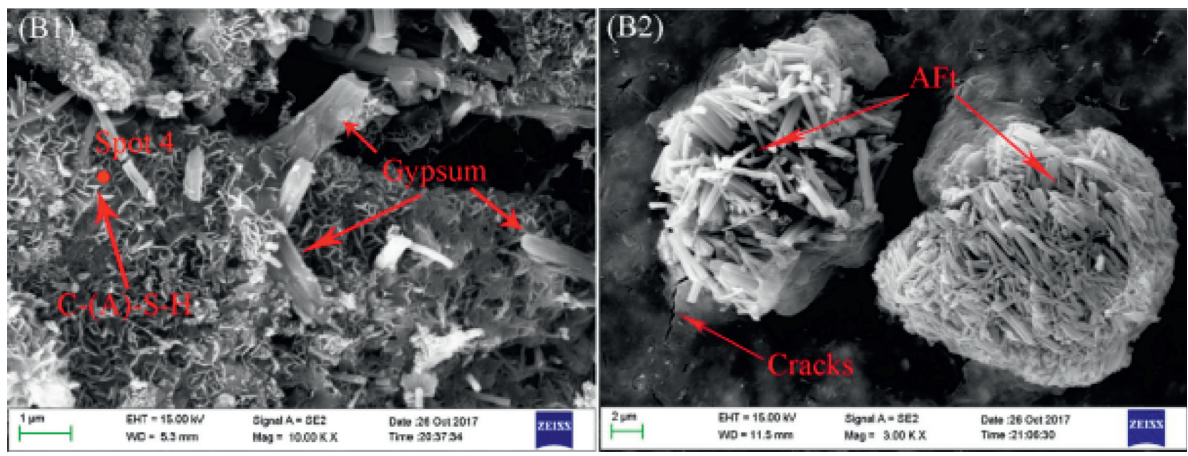

FIgURE 4: Structure of titanium slag and red gypsum cementitious material (from [36]).

Employing the above theory, researchers conducted field tests in Inner Mongolia and found that air-foamed lightweight soil has a significant temperature isolation effect, and the maximum temperature difference can be $10^{\circ}[12,144]$.

4.4. Shock-Absorbing Barriers. The porous structure of airfoamed lightweight soil results in better shock absorption and buffering effects. Research shows that each cubic meter of bubble lightweight soil absorbs energy in the $1.6 \times 10^{3} \mathrm{~N} \bullet \mathrm{m}-2.23 \times 10^{3} \mathrm{~N} \bullet \mathrm{m}$ range, which is four times that of ordinary concrete [145]. Air-foamed lightweight soil can serve as the soft rock buffer layer in high-stress areas, effectively absorbing the creep deformation of the surrounding rock and relieving the creep deformation pressure of the secondary lining [146]. Moreover, as a shock-absorbing barrier, air-foamed lightweight soil is also used in hedge lanes, seismic zone tunnel isolation layers, and the antiexplosion layer of subway tunnels [140].

\section{Current Limitations of and Perspectives on Air-Foamed Lightweight Soil}

5.1. Material. Cement is still the most significant cementitious material for air-foamed lightweight soil; however, using a large amount of cement has deleterious effects. First, carbon emissions, which are not environmentally friendly, are released during cement production. Moreover, cement generates a large amount of hydration heat during reactions, which is not conducive to air-foamed lightweight soil quality control. Finally, the price of cement is too high and would affect the cost of engineering. Therefore, it is important to develop other binder materials to replace cement. In recent years, additional binder materials have effectively improved the performance of air-foamed lightweight soil.

The foaming agent should be made from nontoxic materials to reduce damage to the environment; moreover, it should make the foam that it generates more stable and longlasting. Furthermore, the compatibility between foaming agent types and different raw soils is also a crucial problem to solve.

5.2. Production Method. The production method of airfoamed lightweight soil is an urgent problem that needs to be solved. To date, there has been no professional standard to guide production. Furthermore, the lack of complete construction equipment makes the quality of air-foamed lightweight soil challenging to control, increasing engineering costs and the wastage of raw materials. Therefore, it is necessary to standardize production processes.

5.3. Properties. The properties of air-foamed lightweight soil have been extensively studied. However, research on the structural characteristics of lightweight air-foamed soil, such as the pore types formed by different foams, molding mechanisms of various raw materials, and internal structural characteristics, is limited. Additionally, the trial mixing method is still used in the mixing ratio design of air-foamed lightweight soil even though it has no complete theoretical basis, restricting the development of bubble-blended lightweight soil. As for the durability of air-foamed lightweight soil, we still lack firsthand monitoring data owing to the limited use of airfoamed lightweight soil. For example, (1) simulation of the freeze-thaw temperature field and factors affecting freeze-thaw are complex problems; (2) the dynamic response of the road system and resilience modulus has not been systematically described when air-foamed lightweight soil is applied to the subgrade/subbase; (3) the internal structural characteristics of air-foamed lightweight soil under wetting-drying cycles and the action of salts and alkalis are still the focus of research; and (4) it is also critical to strengthen the inspection of existing engineering using air-foamed lightweight soil and identify problems in a timely manner for future use.

5.4. Application. Air-foamed lightweight soil has been widely applied in soft foundation replacement and dredged soil treatment. However, with respect to innovative applications of air-foamed lightweight soil, countries remain relatively conservative. The cost of airfoamed lightweight soils is a crucial factor that restricts its application; however, studies have revealed that the cost of applying air-foamed lightweight soil is between 240 and 310 yuan per cubic meter, which is lower than that of ordinary concrete. Therefore, it is feasible to apply air-foamed lightweight soil on a large scale through technological improvements. 


\section{Conclusions}

This paper summarizes the material composition and functional characteristics of air-foamed lightweight soil and introduces its current application status. As a new soft soil treatment technology, air-foamed lightweight soil is more convenient than traditional construction materials. As a road-filling material, it has a lower density and good thermal insulation performance. Furthermore, as a backfill material, it exhibits better fluidity and lightness. In addition, airfoamed lightweight soil can dispose of solid waste, which has creative significance for environmental protection. However, the application of bubble lightweight soil technology has been greatly limited owing to the high cost of its raw materials, shortage of manufacturing equipment, uncertainty of environmental adaptability, and inadequacy of durability research. To further develop the technology, it is necessary to study the above limitations further, expand the scope of application, improve equipment and production processes, and establish more standards.

\section{Data Availability}

No data were used to support this study.

\section{Conflicts of Interest}

The authors declare that they have no conflicts of interest.

\section{Acknowledgments}

This work was supported by the National Natural Science Foundation of China (42077262, 42077261, and 41972294).

\section{References}

[1] J. K. Thakur, J. Han, and R. L. Parsons, "Creep behavior of geocell-reinforced recycled asphalt pavement bases," Journal of Materials in Civil Engineering, vol. 25, no. 10, pp. 15331542, 2013.

[2] Z. Feng and R. Zhu, "Status and prospect of the improvement of soft soil on expressway in China," Journal of Wuhan University of Technology, vol. 24, no. 01, pp. 78-80, 2002.

[3] H. Liu and M. Zhao, "Review of ground improvement technical and its application in China," China Civil Engineering Journal, vol. 49, no. 01, pp. 96-115, 2016.

[4] A. Hegde, "Geocell reinforced foundation beds-past findings, present trends and future prospects: a state-of-the-art review," Construction and Building Materials, vol. 154, pp. 658-674, 2017.

[5] Z. Chen and S. Wang, "Review of air-foamed lightweight soil and its application," Journal of China \& Foreign Highway, vol. 23, no. 05, pp. 117-120, 2003.

[6] Y. Yang and B. Chen, "Potential use of soil in lightweight foamed concrete," KSCE Journal of Civil Engineering, vol. 20, no. 6, pp. 2420-2427, 2016.

[7] W. She, Y. Du, G. Zhao, P. Feng, Y. Zhang, and X. Cao, "Influence of coarse fly ash on the performance of foam concrete and its application in high-speed railway roadbeds," Construction and Building Materials, vol. 170, pp. 153-166, 2018.
[8] S. K. Lim, C. S. Tan, B. Li, T.-C. Ling, M. U. Hossain, and C. S. Poon, "Utilizing high volumes quarry wastes in the production of lightweight foamed concrete," Construction and Building Materials, vol. 151, pp. 441-448, 2017.

[9] K. Liu, Q. Su, P. Ni, C. Zhou, W. Zhao, and F. Yue, "Evaluation on the dynamic performance of bridge approach backfilled with fibre reinforced lightweight concrete under high-speed train loading," Computers and Geotechnics, vol. 104, pp. 42-53, 2018.

[10] F. Zhang, D. Yang, and L. Zhang, "Research on filling scheme and deformation properties of wide subgrade of foamed lightweight soil on soft ground," IOP Conference Series: Earth and Environmental Science, ESMA Institute of Physics Publishing, vol. 108, no. 2, Chongqing, China, Article ID 022051, 2017.

[11] T. Satoh, T. Tsuchida, K. Mitsukuri, and Z. Hong, "Field placing test of lightweight treated soil under seawater in Kumamoto Port," Soils and Foundations, vol. 41, no. 5, pp. 145-154, 2001.

[12] H. Zhou, "Research on application technology of air bubble mixed light soil for heat insulation of frozen soil foundation," [B.S dissertation], Central South Unversity, hunan china, 2008.

[13] Y. Gao, M. Xiao, and H. Guan, "Foamed cement banking and its utilization in highway engineering," Bulletin of the Chinese Ceramic Society, vol. 35, no. 08, pp. 2432-2438, 2016.

[14] Y. H. M. Amran, N. Farzadnia, and A. A. Abang Ali, "Properties and applications of foamed concrete; a review," Construction and Building Materials, vol. 101, pp. 990-1005, 2015.

[15] A. Raj, D. Sathyan, and K. M. Mini, "Physical and functional characteristics of foam concrete: a review," Construction and Building Materials, vol. 221, pp. 787-799, 2019.

[16] S. Wang, "Application of foamed cement banking in highway reconstruction and extension project," [B.S dissertation], Chongqing Jiaotong University, Chongqing, China, 2019.

[17] Z. Yan, "evelopment status and trend of foamed concrete," Construction Wall Innovation \& Building Energy-Saving, no. 06, pp. 19-23, 2011.

[18] L. Chica and A. Alzate, "Cellular concrete review: new trends for application in construction," Construction and Building Materials, vol. 200, pp. 637-647, 2019.

[19] G. Samson, A. Phelipot-Mardele, and C. Lanos, "Thermal and mechanical properties of gypsum-cement foam concrete: effects of surfactant," European Journal of Environmental and Civil Engineering, vol. 21, no. 12, pp. 1502-1521, 2017.

[20] E. P. Kearsley and P. J. Wainwright, "The effect of high fly ash content on the compressive strength of foamed concrete," Cement and Concrete Research, vol. 31, no. 1, pp. 105-112, 2001.

[21] Y.-D. Zhou, Y. Wang, B. Li, J.-H. Xu, M.-C. Liu, and H. M. Ali, "Study of the preparation of air-foam treated lightweight soil samples," Yantu Lixue/Rock and Soil Mechanics, vol. 39, no. 12, pp. 4413-4420, 2018.

[22] Y. Watabe and T. Noguchi, "Site-investigation and geotechnical design of D-runway construction in Tokyo Haneda airport," Soils and Foundations, vol. 51, no. 6, pp. 1003-1018, 2011.

[23] H. V. Vo and D. W. Park, "Lightweight treated soil as a potential sustainable pavement material," Journal of Performance of Constructed Facilities, vol. 30, no. 1, Article ID C4014009, 2016. 
[24] Z. Q. Zhang and J. L. Yang, "Improving safety of runway overrun through foamed concrete aircraft arresting system: an experimental study," International Journal of Crashworthiness, vol. 20, no. 5, pp. 448-463, 2015.

[25] E. K. K. Nambiar and K. Ramamurthy, "Models relating mixture composition to the density and strength of foam concrete using response surface methodology," Cement and Concrete Composites, vol. 28, no. 9, pp. 752-760, 2006.

[26] E. K. K. Nambiar and K. Ramamurthy, "Influence of filler type on the properties of foam concrete," Cement and Concrete Composites, vol. 28, no. 5, pp. 475-480, 2006.

[27] M. R. Ahmad, B. Chen, and S. Farasat Ali Shah, "Investigate the influence of expanded clay aggregate and silica fume on the properties of lightweight concrete," Construction and Building Materials, vol. 220, pp. 253-266, 2019.

[28] M. R. Jones and A. McCarthy, "Heat of hydration in foamed concrete: effect of mix constituents and plastic density," Cement and Concrete Research, vol. 36, no. 6, pp. 1032-1041, 2006.

[29] Q. Shan, "Experimental study on thermal insulation performance of foamed cement banking (FCB)in subgrade cushion," [B.S dissertation], Taiyuan University of Technology, Shanxi, China, 2018.

[30] Z. Pan, H. Li, and W. Liu, "Preparation and characterization of super low density foamed concrete from Portland cement and admixtures," Construction and Building Materials, vol. 72, pp. 256-261, 2014.

[31] H. Awang, Z. S. Aljoumaily, N. Noordin, and M. Z. AlMulali, "The mechanical properties of foamed concrete containing un-processed blast furnace slag," MATEC Web of Conferences, vol. 15, no. 6, p. 01034, 2014.

[32] A. F. Angelin, R. C. C. Lintz, and L. A. G. Barbosa, "Use of expanded clay and silica fume for the improvement of mechanical, physical and thermal performances of structural lightweight concretes," Materia-Rio De Janeiro, vol. 22, 2017.

[33] T. Tian, Y. Yan, Z. Hu, Y. Xu, Y. Chen, and J. Shi, "Utilization of original phosphogypsum for the preparation of foam concrete," Construction and Building Materials, vol. 115, pp. 143-152, 2016.

[34] Y. Chen, "Experimental study on satic and dynamic characteristics of foamed cement banking mixed by waste gypsum," [B.S dissertation], Shenyang jianzhu University, China, Liaoning, 2019.

[35] X. Yao, W. Wang, M. Liu, Y. Yao, and S. Wu, "Synergistic use of industrial solid waste mixtures to prepare ready-to-use lightweight porous concrete," Journal of Cleaner Production, vol. 211, pp. 1034-1043, 2019.

[36] J. Zhang, Y. Yan, and Z. Hu, "Preparation and characterization of foamed concrete with Ti-extracted residues and red gypsum," Construction and Building Materials, vol. 171, pp. 109-119, 2018.

[37] B. Gao, Q. Wang, and X. Zhou, "Study on foaming agent of concrete and stability of foam," Fly Ash Comprehensive Utilization, no. 01, pp. 13-16, 2004.

[38] M. Dai, Z. He, and X. Fang, "Experimental study on preparation of foamed concrete by solid foaming agent," New Building Materials, vol. 44, no. 10, pp. 97-99+115, 2017.

[39] Y. Ma, K. Li, S. Ming, X. Yang, and S. Ma, "Research on the preparation of ultra - low density foamed cement," Fly Ash Comprehensive Utilization, no. 05, pp. 3-6+11, 2016.

[40] J. Liu and Y. L. Sun, "Flexural performance study of glass fiber reinforced foam concrete with hydrogen peroxide," in Proceedings of the 2015 International Conference on Materials
Chemistry and Environmental Protection, P. M. Pardalos and B. Bhushan, Eds., Sanya, China, January 2016.

[41] L. Y. Ming, A. V. Sandu, H. C. Yong et al., "Compressive strength and thermal conductivity of fly ash geopolymer concrete incorporated with lightweight Aggregate, expanded clay aggregate and foaming agent," Revista de Chimie, vol. 70, no. 11, pp. 4021-4028, 2019.

[42] "Technical specification for foamed mixture lightweight soil filling engineering," China - Industry standard - Industry standard - Urban construction CN-CJ,(CJJ/T 177-2012), 2012.

[43] D. Aldridge, "Introduction to foamed concrete: what, why, how?" Proc., International Conference on Use of Foamed Concrete in Construction, pp. 1-14, Dundee, Scotland,UK, 2005.

[44] D. K. Panesar, "Cellular concrete properties and the effect of synthetic and protein foaming agents," Construction and Building Materials, vol. 44, pp. 575-584, 2013.

[45] L. D. Rose and J. Morris, "The influence of the mix design on the properties of micro-cellular concrete," in Proceedings of the International conference on specialist techniques and materials for concrete construction, pp. 185-198, Dundee, Scotland,UK, September 1999.

[46] C. Bing, W. Zhen, and L. Ning, "Experimental research on properties of high-strength foamed concrete," Journal of Materials in Civil Engineering, vol. 24, no. 1, pp. 113-118, 2012.

[47] P. J. Tikalsky, J. Pospisil, and W. Macdonald, "A method for assessment of the freeze-thaw resistance of preformed foam cellular concrete," Cement and Concrete Research, vol. 34, no. 5, pp. 889-893, 2004.

[48] Y. Xiong, Y. Zhu, C. Chen, and Y. Zhang, "Effect of nanoalumina modified foaming agents on properties of foamed concrete," Construction and Building Materials, vol. 267, Article ID 121045, 2021.

[49] N. Beningfield, R. Gaimster, and P. Griffin, "Investigation into the air void characteristics of foamed concrete," Proc., International Conference on Use of Foamed Concrete in Construction, pp. 51-60, Dundee, Scotland,UK, 2005.

[50] M. A. Rasheed and S. S. Prakash, "Behavior of hybridsynthetic fiber reinforced cellular lightweight concrete under uniaxial tension - experimental and analytical studies," Construction and Building Materials, vol. 162, pp. 857-870, 2018.

[51] S.-C. Ng, K.-S. Low, and N.-H. Tioh, "Potential use of clayey soil in aerated lightweight concrete," KSCE Journal of Civil Engineering, vol. 16, no. 5, pp. 809-815, 2012.

[52] T. D. Wang, L. L. Yang, G. C. Jiang, P. F. Luckham, and X. Yang, "Enhanced foam-stabilizing performance by the addition of clays: a comparison of magnesium aluminum silicate with sodium bentonite," Applied Clay Science, vol. 189, Article ID 105558, 2020.

[53] K.-H. Lee, K.-H. Yang, J.-H. Mun, and N. Van Tuan, "Effect of sand content on the workability and mechanical properties of concrete using bottom ash and dredged soil-based artificial lightweight Aggregates," International Journal of Concrete Structures and Materials, vol. 13, no. 1, 2019.

[54] Y. T. Kim, J. Ahn, W. J. Han, and M. A. Gabr, "Experimental evaluation of strength characteristics of stabilized dredged soil," Journal of Materials in Civil Engineering, vol. 22, no. 5, pp. 539-544, 2010.

[55] M. T. Spyridopoulos and S. J. R. Simons, "Effect of natural organic matter on the stability of a liquid film between two colliding bubbles," Colloids and Surfaces A-Physicochemical and Engineering Aspects, vol. 235, no. 1-3, pp. 25-34, 2004. 
[56] Y. S. Peng, J. Jiang, X. D. Ou, and J. X. Qin, "Investigating the properties of foamed mixture lightweight soil mixed with bauxite tailings as filler," Advances in Materials Science and Engineering, vol. 2019, Article ID 6295348, 10 pages, 2019.

[57] Z. M. Jaini, R. H. M. Rum, and K. H. Boon, "Strength and fracture energy of foamed concrete incorporating rice husk ash and polypropylene mega-mesh 55," Iop International Conference on Structural, Mechanical and Materials Engineering, vol. 248, no. 1, Article ID 012005, 2017.

[58] S. K. Lim, C. S. Tan, O. Y. Lim, and Y. L. Lee, "Fresh and hardened properties of lightweight foamed concrete with palm oil fuel ash as filler," Construction and Building $M a$ terials, vol. 46, pp. 39-47, 2013.

[59] E. K. Kunhanandan Nambiar and K. Ramamurthy, "Fresh state characteristics of foam concrete," Journal of Materials in Civil Engineering, vol. 20, no. 2, pp. 111-117, 2008.

[60] S. Horpibulsuk, A. Suddeepong, A. Chinkulkijniwat, and M. D. Liu, "Strength and compressibility of lightweight cemented clays," Applied Clay Science, vol. 69, pp. 11-21, 2012.

[61] E. P. Kearsley and M. Visagie, "Micro-properties of foamed concrete," Proc., International Conference on Specialist Techniques and Materials for concrete Construction, , Dundee, Scotland,UK, 1999pp. 173-184, Sep.8-10.

[62] E. P. Kearsley, The Use of Foamed concrete for Affordable Development in Third World Countries, 1996.

[63] T.-H. Kim, G.-C. Kang, and L.-K. Park, "Development and mechanical strength properties of a new lightweight soil," Environmental Earth Sciences, vol. 72, no. 4, pp. 1109-1116, 2014.

[64] G. He, Z. Ding, and Y. Zheng, "Preparation of bubble mixed light soil and its properties," Chinese Journal of Underground Space and Engineering, vol. 5, no. 01, pp. 18-22, 2009.

[65] A. Neramitkornburi, S. Horpibulsuk, S. L. Shen, A. Arulrajah, and M. Miri Disfani, "Engineering properties of lightweight cellular cemented clay-fly ash material," Soils and Foundations, vol. 55, no. 2, pp. 471-483, 2015.

[66] D. De Sarno, E. Vitale, D. Deneele et al., "Effects of cement and foam addition on chemo-mechanical behaviour of lightweight cemented soil (LWCS)," E3S Web of Conferences, EDP Sciences, vol. 92, p. 11006, Glasgow, United kingdom, 2019.

[67] B. Lin, Y.-y. Zhang, Q. Yang, H.-q. Liu, and Z. Ling-ling, "Test and research on the bearing ratio of bubble mixed light soil based on orthogonal design," Highway, vol. 61, no. 09, pp. 108-111, 2016.

[68] P. Jongpradist, S. Youwai, and C. Jaturapitakkul, "Effective void ratio for assessing the mechanical properties of cementclay admixtures at high water content," Journal of Geotechnical and Geoenvironmental Engineering, vol. 137, no. 6, pp. 621-627, 2011.

[69] Y. Li, L. Zhu, J. Li, S. Hu, C. Duan, and X. Wang, "Study on mix ratio design of foamed concrete," Journal of Xuzhou Institute of Technology(Natural Sciences Edition), vol. 26, no. 02 , pp. 1-5+90, 2011.

[70] T. Wako, T. Tsuchida, Y. Matsunaga, K. Hamamoto, T. Kishida, and T. Fukasawa, "Use of artificial light weight materials (treated soil with air form) for port facilities," Doboku Gakkai Ronbunshu, vol. 1998, no. 602, pp. 35-52, 1998.

[71] M. R. Jones, K. Ozlutas, and L. Zheng, "Stability and instability of foamed concrete," Magazine of Concrete Research, vol. 68, no. 11, pp. 542-549, 2016.
[72] Specifications for Design of Highway Subgrades"(JTG D302004) Industry Standard - Transportation, China, 2004.

[73] Y. Qiu, Y. Li, M. Li, Y. Liu, and L. Zhang, "Experimental study on microstructure characters of foamed lightweight soil," IOP Conference Series: Earth and Environmental Science, Institute of Physics Publishing, vol. 108, no. 2, Chongqing, China, Article ID 022052, 2017.

[74] M. Cong and C. Bing, "Properties of a foamed concrete with soil as filler," Construction and Building Materials, vol. 76, pp. 61-69, 2015.

[75] M. R. Jones, M. J. Mccarthy, and A. Mccarthy, "Moving fly ash utilisation in concrete forward: a UK perspective," 2003.

[76] A. F. Roslan, H. Awang, and M. A. O. Mydin, "Effects of various additives on drying shrinkage, compressive and flexural strength of lightweight foamed concrete (LFC)," Advanced Materials Research, vol. 626, pp. 594-604, 2012.

[77] P. Chindaprasirt, S. Rukzon, and V. Sirivivatnanon, "Resistance to chloride penetration of blended Portland cement mortar containing palm oil fuel ash, rice husk ash and fly ash," Construction and Building Materials, vol. 22, no. 5, pp. 932-938, 2008.

[78] K. Ramamurthy and N. Narayanan, "Influence of composition and curing on drying shrinkage of aerated concrete," Materials and Structures, vol. 33, no. 228, pp. 243-250, 2000.

[79] E. K. K. Nambiar and K. Ramamurthy, "Sorption characteristics of foam concrete," Cement and Concrete Research, vol. 37, no. 9, pp. 1341-1347, 2007.

[80] E. P. Kearsley, The Effect of High Volumes of Ungraded Fly Ash on the Properties of Foamed concrete, university of leeds, woodhouse UK, 1999.

[81] E. K. Kunhanandan and K. Ramamurthy, "Shrinkage behavior of foam concrete," Journal of Materials in Civil Engineering, vol. 21, no. 11, pp. 631-636, 2009.

[82] K. Ramamurthy, E. K. Kunhanandan Nambiar, and G. Indu Siva Ranjani, "A classification of studies on properties of foam concrete," Cement and Concrete Composites, vol. 31, no. 6, pp. 388-396, 2009.

[83] C. Yu, "Foam concrete performance study based on experimental analysis," in International Conference on Energy, Materials and Manufacturing Engineering, J. W. Gu et al., Ed., vol. 25p. 04005, 2015.

[84] M. Ding, "A study on the property of foam concrete with water repellents," [B.S dissertation], Hunan University, Hunan China, 2011.

[85] A. Steshenko, A. Kudyakov, V. Konusheva, and O. Syrkin, "Structure formation control of foam concrete," in Proceedings of the Youth, Science, Solutions: Ideas and Prospects, N. O. Kopanitsa, Ed., , November 2017.

[86] J. Otani, T. Mukunoki, and Y. Kikuchi, "Visualization for engineering property of in-situ light weight soils with air foams," Soils and Foundations, vol. 42, no. 3, pp. 93-105, 2002.

[87] S. K. Lim, C. S. Tan, X. Zhao, and T. C. Ling, "Strength and toughness of lightweight foamed concrete with different sand grading," Ksce Journal of Civil Engineering, vol. 19, no. 7, pp. 2191-2197, 2015.

[88] H. Fujiwara, E. Sawada, and Y. Ishikawa, "Manufacture of high-strength aerated concrete containing silica fume," Proc., 5th International Conference on Fly Ash, Silica Fume, Slag, and Natural Pozzolans in Concrete, vol. 153, pp. 779-794, 1995.

[89] M. A. O. Mydin, M. Musa, and A. N. A. Ghani, "Fiber glass strip laminates strengthened lightweight foamed concrete: performance index, failure modes and microscopy analysis," 
in Proceedings of the 3rd International Conference on Applied Science and Technology, F. A. A. Nifa et al., Ed., , Pulau Pinang, Malaysia, 2018.

[90] M. A. O. Mydin, N. Mohamad, A. A. A. Samad, I. Johari, and M. A. C. Munaaim, "Durability performance of foamed concrete strengthened with chemical treated $(\mathrm{NaOH})$ coconut fiber," in Proceedings of the 3rd International Conference on Applied Science and Technology, F. A. A. Nifa et al., Ed., , Pulau Pinang, Malaysia, 2018.

[91] M. S. Mahzabin, L. J. Hock, M. S. Hossain, and L. S. Kang, "The influence of addition of treated kenaf fibre in the production and properties of fibre reinforced foamed composite," Construction and Building Materials, vol. 178, pp. 518-528, 2018.

[92] B. Raj, D. Sathyan, M. K. Madhavan, and A. Raj, "Mechanical and durability properties of hybrid fiber reinforced foam concrete," Construction and Building Materials, vol. 245, Article ID 118373, 2020.

[93] N. M. Zamzani, M. A. O. Mydin, and A. N. A. Ghani, "Experimental investigation on engineering properties of lightweight foamed concrete (LFC) with coconut fiber addition," in 12th International Civil Engineering Post Graduate Conference, Y. Haryati et al., Ed., vol. 250, no. 17, p. 05005, 2018.

[94] M. H. Ahmad and H. Awang, "Effect of steel and alkalineresistance glass fibre on mechanical and durability properties of lightweight foamed concrete," in Advanced Materials Research, M. M. A. Abdullah et al., Ed., vol. 626pp. 404-410, 2012.

[95] O. Kayall, M. N. Haque, and B. Zhu, "Some characteristics of high strength fiber reinforced lightweight aggregate concrete," Cement and Concrete Composites, vol. 25, no. 2, pp. 207-213, 2003.

[96] N. M. Mhedi, A. A. Hilal, and A. Al-Hadithi, "Re-use of waste plastic as fibers in production of modified foamed concrete," in Proceedings of the 2018 11th International Conference on Developments in Esystems Engineering, pp. 295-299, IEEE, Cambridge, UK, September 2018.

[97] Y. Kim, H. Kim, and G. Lee, "Mechanical behavior of lightweight soil reinforced with waste fishing net," Geotextiles and Geomembranes, vol. 26, no. 6, pp. 512-518, 2008.

[98] X. J. Tan, W. Z. Chen, H. Y. Liu, and A. H. C. Chan, "Stressstrain characteristics of foamed concrete subjected to large deformation under uniaxial and triaxial compressive loading," Journal of Materials in Civil Engineering, vol. 30, no. 6, 2018.

[99] C. Zhou, "Mechanical properties the cast in situ foamed lightweight soil," Key Engineering Materials, vol. 703, pp. 411-415, 2016.

[100] X. N. Shi, J. J. Huang, and Q. Su, "Experimental and numerical analyses of lightweight foamed concrete as filler for widening embankment," Construction and Building Materials, vol. 250, 2020.

[101] G.-L. Yoon and Y. S. kyong, "Strength and deformation characteristics of lightweight foamed soil using in-situ soil," Journal of the korean geotechnical society, vol. 20, no. 9, pp. 116-125, 2004.

[102] M. Nehdi, Y. Djebbar, and A. Khan, "Neural network model for preformed-foam cellular concrete," ACI Materials Journal, vol. 98, no. 5, pp. 402-409, 2001.

[103] A. Ashrafian, F. Shokri, M. J. T. Amiri, Z. M. Yaseen, and M. Rezaie-Balfd, "Compressive strength of Foamed Cellular Lightweight Concrete simulation: new development of hybrid artificial intelligence model," Construction and Building Materials, vol. 230, 2020.

[104] N. N. Ramamurthy, "Structure and properties of aerated concrete: a review," Cement and Concrete Composites, vol. 21, no. 5, pp. 321-329, 2000.

[105] K. Byun, H. Song, S. Park, and Y. Song, "Development of structural lightweight foamed concrete using polymer foam agent," Congr. Polym. Concr.vol. 19, 1998.

[106] A. A. Hilal, N. H. Thom, and A. R. Dawson, "Failure mechanism of foamed concrete made with/without additives and lightweight Aggregate," Journal of Advanced Concrete Technology, vol. 14, no. 9, pp. 511-520, 2016.

[107] J. Huang, G. X. Tian, P. Y. Huang, and Z. B. Chen, "Flexural performance of sisal fiber reinforced foamed concrete under static and fatigue loading," Materials, vol. 13, no. 14, p. 3098, 2020.

[108] R. Allouzi, A. Al Qatawna, and T. Al-Kasasbeh, "Lightweight foamed concrete mixture for structural use," ACI Materials Journal, vol. 117, no. 3, pp. 99-109, 2020.

[109] A. A. Jhatial, W. I. Goh, S. Sohu, and N. Mohamad, “Thermomechanical properties of various densities of foamed concrete incorporating polypropylene fibres," Arabian Journal for Science and Engineering, vol. 45, no. 10, pp. 8171-8186, 2020.

[110] Y. Yang, Q. Zhou, Y. Deng, and J. Lin, "Compressive behaviors of ultra-low-weight foamed cement-based composite reinforced by polypropylene short fibers," International Journal of Damage Mechanics, vol. 29, no. 8, pp. 1306-1325, 2020.

[111] L. Yu and Z. L. Liu, "Mechanical properties optimization of fiber reinforced foam concrete," in MATEC Web of Conferences, M. Jawaid and E. R. Kenawy, Eds., vol. 67p. 03022, 2016.

[112] K. C. Brady, M. R. Jones, and G. R. Watts, Specification for Foamed concrete, Application guide AG39: TRL Limited, Crowthorne, United Kingdom, 2001.

[113] F. C. McCormick, Rational Proportioning of Preformed Foam Cellular concrete, 1967.

[114] L.-y. Wan, "Machanical properties and application in subgrade of cement-based foamed concrete with silt," [B.S dissertation], Shandong University, China, Shandong, 2019.

[115] Z.-p. Chen, J.-b. Wang, J.-f. Liu, and W.-h. Zhao, "Experimental study on dynamic engineering characteristics of foamed lightweight soil," Highway, vol. 64, no. 02, pp. 77-80, 2019.

[116] Y. Watabe, H. Saegusa, H. Shinsha, and T. Tsuchida, "Ten year follow-up study of airfoam-treated lightweight soil," Proceedings of the Institution of Civil Engineers - Ground Improvement, vol. 164, no. 3, pp. 189-200, 2011.

[117] X. B. Huang, C. Y. Liu, Y. H. Wangren et al., "Cause analysis and countermeasures of through shakes in foamed concrete subgrade," Advances in Civil Engineering, vol. 2019, Article ID 7958285, 15 pages, 2019.

[118] X. Liu, C. W. Ni, H. Ji, S. Y. Tan, and B. N. Hong, "Construction techniques and quality test and evaluation of lightweight cellular concrete mixed with fly ash as subgrade material," Advances in Materials Science and Engineering, vol. 2019, Article ID 5402679, 12 pages, 2019.

[119] X. Liu, C. W. Ni, L. Y. Zhang, K. Sheng, and B. N. Hong, "Durability assessment of lightweight cellular concrete in subgrade by the method of analytic hierarchy process combined with fuzzy comprehensive evaluation," Mathematical Problems in Engineering, vol. 2019, Article ID 4915870, 10 pages, 2019. 
[120] Y.-d. Zhou, J.-h. Xu, L. Bing, Y. Wang, and A. H. Mahfouz, "Influence of freeze-thaw cycles on physical characteristics of air-foam treated lightweight soil," Henan Science, vol. 36, no. 02, pp. 198-203, 2018.

[121] G. He, A. Deng, and Y. Wang, "Influence of Freeze-thaw cycles on compressive strength of bubble light soil," Journal of Logistical Engineering University, vol. 28, no. 04, pp. 1-6, 2012.

[122] S. Bin-Shafique, K. Rahman, M. Yaykiran, and I. Azfar, "The long-term performance of two fly ash stabilized fine-grained soil subbases," Resources, Conservation and Recycling, vol. 54, no. 10, pp. 666-672, 2010.

[123] Q. Xu, L. Liu, X. Wang, P. Wen, and G. Yu, "Strength analysis of the cast-in-situ foamed lightweight soil materials," in Proceedings of the 2019 5th International Conference on Hydraulic and Civil Engineering, ICHCE 2019, May 2019.

[124] A. Neramitkornburi, S. Horpibulsuk, S. L. Shen, A. Chinkulkijniwat, A. Arulrajah, and M. M. Disfani, "Durability against wetting-drying cycles of sustainable Lightweight Cellular Cemented construction material comprising clay and fly ash wastes," Construction and Building Materials, vol. 77, pp. 41-49, 2015.

[125] G.-b. Ye, J.-t. Liu, Z. Zhang, F. Rao, J. Chen, and J. Zhang, "Dynamic strength and prediction model of foamed concrete under cyclic loading," Construction Technology, vol. 49, no. 09, pp. 50-53, 2020.

[126] T. Li, Z. Han, D. Cai et al., "Structure mechanical characteristics of lightweight concrete subgrade of heavy haul railway with $35 \sim 40$ t axle load," Railway Engineering, vol. 60, no. 04, pp. 140-144, 2020.

[127] X. Liu, K. Sheng, Z. L. Li, L. Q. Gan, H. Shan, and B. N. Hong, "Experimental research on foamed mixture lightweight soil mixed with fly-ash and quicklime as backfill material behind abutments of expressway bridge," Advances in Materials Science and Engineering, vol. 2017, Article ID 5767103, 11 pages, 2017.

[128] P. Chen, R. Zeng, S. C. Bian, and Feng, "Study on long term durability of road foam concrete," New Building Materials, vol. 45, no. 07, pp. 33-36, 2018.

[129] H. T. Cao, L. Bucea, A. Ray, and S. Yozghatlian, "The effect of cement composition and $\mathrm{pH}$ of environment on sulfate resistance of Portland cements and blended cements," Cement and Concrete Composites, vol. 19, no. 2, pp. 161-171, 1997.

[130] P. Brown, R. D. Hooton, and B. Clark, "Microstructural changes in concretes with sulfate exposure," Cement and Concrete Composites, vol. 26, no. 8, pp. 993-999, 2004.

[131] M. Sahmaran, O. Kasap, K. Duru, and I. O. Yaman, "Effects of mix composition and water-cement ratio on the sulfate resistance of blended cements," Cement and Concrete Composites, vol. 29, no. 3, pp. 159-167, 2007.

[132] M. Hu, T. Xiang, D. Chen, and H. Gao, "A study of resistance to chloride ion penetration of foam concrete," Journal of Anhui University of Technology, vol. 37, no. 01, pp. 80-86, 2020.

[133] G. Indu Siva Ranjani and K. Ramamurthy, "Behaviour of foam concrete under sulphate environments," Cement and Concrete Composites, vol. 34, no. 7, pp. 825-834, 2012.

[134] T.-H. Kim, T.-H. Kim, and G.-C. Kang, "Performance evaluation of road embankment constructed using lightweight soils on an unimproved soft soil layer," Engineering Geology, vol. 160, pp. 34-43, 2013.

[135] Z. X. Du, W. She, W. Q. Zuo, J. X. Hong, Y. S. Zhang, and C. W. Miao, "Foamed gypsum composite with heat-resistant admixture under high temperature: mechanical, thermal and deformation performances," Cement and Concrete Composites, vol. 108, Article ID 103549, 2020.

[136] K.-S. Oh and T.-H. Kim, "Dependence of the material properties of lightweight cemented soil on the curing temperature," Journal of Materials in Civil Engineering, vol. 26, no. 7, Article ID 06014008, 2014.

[137] C. Teerawattanasuk, P. Voottipruex, and S. Horpibulsuk, "Mix design charts for lightweight cellular cemented Bangkok clay," Applied Clay Science, vol. 104, pp. 318-323, 2015.

[138] J.-j. Huang, Q. Su, W.-h. Zhao, T. Li, and X.-x. Zhang, "Experimental study on use of lightweight foam concrete as subgrade bed filler of ballastless track," Construction and Building Materials, vol. 149, pp. 911-920, 2017.

[139] Q. Su, W.-h. Zhao, Y.-w. Wang, and Z.-p. Chen, "Technical and economical comparison among treatment schemes of road and bridge transition section with deep soft foundation on expressway," Highway, vol. 61, no. 01, pp. 52-56, 2016.

[140] "China foamed concrete industry development report 2019," China Concrete, no. 05, pp. 18-26, 2020.

[141] Y.-q. Wu, B.-y. Li, X.-l. Huang, B. Qian, and X.-l. He, "Comparative analysis of the effects of different treatment methods on bridge head roadbed with thick overburden around Hangzhou Bay," Science Technology and Engineering, vol. 20, no. 13, pp. 5305-5312, 2020.

[142] N. M. Zahari, I. A. Rahman, A. Mujahid, and A. Zahidi, Foamed concrete: Potential Application in thermal Insulation, Universiti Malaysia Pahang, Pahang, Malaysia, 2009.

[143] A. Giannakou and M. R. Jones, Potential of Foamed Concrete to Enhance the Thermal Performance of Low-Rise Dwellings, Thomas Telford, 2002.

[144] W. Hao, B. Yang, and L. Wu, "Application of light-weight soil in road in cold region," Highways \& Transportation in Inner Mongolia, no. 03, pp. 5-9, 2005.

[145] S. Li, "Impact test and and finite element analysis of foamed light-weight cement based on the airport pavement," [B.S dissertation], Nanjing University of Aeronautics and Astronautics, Nanjing China, 2012.

[146] W. Chen, H. Tian, F. Yang, and Y. Geng, "Study of effects of foam concrete preset deformation layer on long-term stability of deep soft rock tunnel," Rock and Soil Mechanics, vol. 32, no. 09, pp. 2577-2583, 2011. 